\title{
Understanding the Economic Growth of Indonesia
}

\author{
Singgih Tri Sulistiyono
}

History Department, Diponegoro University Semarang

Jan Luiten van Zanden \& Daan Marks, Ekonomi Indonesia 1800-2010: Antara Drama dan Keajaiban Pertumbuhan. Jakarta: Penerbit Buku Kompas \& KITLV-Jakarta, 2012. xix+491 pp. ISBN 978-979-709-678-6

\section{Introduction}

Once again, Indonesian economic history obtains admiration to receive an extraordinary thought from authoritative experts on their fields of study, i.e. Professor Jan Luiten Van Zanden and Dr. Daan Marks by publishing their book entitles 'An Economic History of Indonesia, 1800-2012' (hereinafter referred to as EHI). Jan Luiten Van Zanden is Professor of Global Economic History at Utrecht University, the Netherlands. He has published tens of books concerning the processes of long-term economic development in Europe and Asia. He is also the senior researcher at the Center for Economic Policy Research (CEPR), an internationally recognized research institution homebased in London. ${ }^{1}$ In the meantime, Dr. Daan Marks is Ph.D. graduate in economies at the same university. He is now a senior economist at the Dutch Ministry of Finance. By looking at the reputation of the authors, literature on the Indonesian economic history is enriched by the research conducted by economists who care about economic history.

\section{Historiographical Notes}

\section{Oasis in the desert}

It should be acknowledged that EHI is filling up the absence of Indonesian economic history textbook following the publication of Howard Dick, Thomas Lindblad, Vincent Houben, and Thee Kian Wie since ten years ago. ${ }^{2}$ Indeed after such a publication there have been efforts to enrich the publication of Indonesian economic history although it limited in the form of anthology, a collection

1 'Center Economic Policy Research', in: http://www.cepr.org/researchers/ details/rschcontact.asp?IDENT=161704

2 Howard W. Dick, Vincent J.H. Houben, J. Thomas Lindblad, and Thee Kian Wie, The Emergence of A National Economy: An Economic History of Indonesia, 1800 - 2000 (Crows Nest, NSW: Allen \& Unwin, 2002). An excellent description concerning the development of Indonesian economic historiography till 1993 can be found in J. Thomas Lindblad, "Key Theme in the Modern Economic History of Indonesia", in: J. Thomas Lindblad (ed.), New Challenges in the Modern Economic History of Indonesia (Leiden: Programme of Indonesian Studies, 1993). In the meantime, the development of historiography of Indonesian economic history written by Indonesian historians since 1990 can be read in Nawiyanto, "Trend in the Economic Historiography of Indonesia since 1990", in: J. Thomas Lindblad \& Bambang Purwanto, Merajut Sejarah Ekonomi Indonesia, pp. 91 - 134. 
of various writings. ${ }^{3}$ It is the fact that up to the present day, most of works on Indonesian economic history either written by Indonesians or foreigners published both in Indonesia and abroad are in the form of anthology. The book of The Eemergence of A National Economy (2002) written by Howard Dick and his companions is actually also an anthology. One of the obvious weaknesses of anthology is lack of coherence among the chapters and/ or articles. This gives rise an impact that the understanding of the readers toward Indonesian economic history is not comprehensive. Moreover, the problem of incomprehensiveness will be more obvious if each article in the anthology has its own focus, analysis, dan perspective.

\section{Chronological approach}

Although EHI is written by two writters, it is not an anthology. It is realy a coherence book. It is not an exaggeration to say that the writers have excellent manner to give explanation on the long-term development of Indonesian economic history. In order to get easer understanding the long-term trend of Indonesian economic history during the last 200 years (from 1800 to 2012), EHI offers a chronological account of the development of Indonesian economy. It is different with those of Anne Booth's work entitles The Indonesian Economy in the Nineteenth and Twentieth Centuries: A History of Missed Opportunities which offers a themathic approach. From this perspective, EHI is possibly easier to be understood for historians appart their difficulties to comprehend econometric. It is

3 These can be mentioned among other: Sri Margana dan Widya Fitrianingsih, Sejarah Indonesia: Perspektif Lokal dan Global, Persembahan untuk 70 Tahun Prof. Dr. Djoko Suryo (Yogyakarta: Ombak, 2010); J. Th. Lindblad \& Bambang Purwanto, Merajut Sejarah Ekonomi Indonesia: Essays in Honour of Thee Kian Wie, 75 Years Birthday (Yogyakarta: Ombak, 2010); Sri Margono, dkk., Sejarah Pangan di Indonesia: Strategi dan Politik Pangan dari Masa Kolonialsampai Reformasi (Yogyakarta: Direktorat Geografi Sejarah Kementerian Kebudayaan dan Pariwisata, 2010). true, for the economists who are interested ini certain key developments (for example: growth, distribution, policy, innovation) may prefer a thematic ordering of the material. But EHI which is telling the story chronologically has certain advantages in the sense that it makes easier to analyze the changes in institutions, policies and their economic outcomes in a consistent way.

Chronological approach of this book can be seen from the sequence analysis reflected in the table of contents. Overall the book is divided into 9 chapters. Chapter 1 is an introduction containing discussion on whether economic growth in Indonesia as a drama or a miracle. In the meantime, Chapter 2 is a general analysis on the proximate and ultimate causes of 200 years of economic growth in Indonesia between 1800 till 2000. Chronological discussion actually started only in Chapter 3 . The title of Chapter 3 is "Colonial State Formation, 1800 to 1830 " which actually covers the period of "trial and error" that reflects a time when the colonial government was still anxious whether to apply a conservative system as implemented by the VOC or more liberalistic system as a result of the influence of the French revolution. In general, we can say that this period was marked by colonial efforts to build a more liberal regime in the colony. EHI argues that liberal regims of 1808 - 1826 had been unable to solve two problems inherited from the VOC. They had tried to create a purely 'public' state although this was very risky and expensive experiments. It was very risky because the colonial government had to estrange indigenous elites who were not completely prepared to be changed as a part of rational bureaucrat. This effort could be expensive because the alternative way, i.e. hired Dutch administrators, was indeed very costly, and of course the development of indigenous economy would be harmed by such kind of policy. EHI concludes that the first liberal experiment had failed. 
Chapter 4 entitles "The Cultivation System, 1830 - 1870". In this chapter, EHI draws a conclusion that the period 1830 - 1870 was a difficult era for the Javanese economy because its growth was slow and total factor productivity declined. It closely linked with some factors, amongst other: institutions for market exchange were not well developed, interest rates were extrimely high, the market for rice (reflected indegenous economy) was quite unstable caused the incentives for peasant to increase marketed output was low. At the same time, total factor productivity declined and fast export growth in the 1830s was followed by the stagnation and even famine in 1840s. Likewise, ineficiency during the Cultivation System also caused it unsustainable in the long run. Apart from the victory of the liberals in the Netherlands in the mid 1850's which traditionally became the reason of the abolishion of Cultivation System, the program itself was already weak when viewed from an economic standpoint.

In Chapter 5, the EHI analyzes the economic change in Indonesia between 1870 and 1914. This period is sharply marked by marked-oriented policies for stimulating economic development. During this period of liberalization, Indonesian economy experienced a significan growth. With the Agrarian Law and the Sugar Law, Western agricultural enterprises were given more opportunities for expansion in line with the decline of Ciltivation System program. Although the liberal system suceeded to stimulate the Indonesian economic growth, the prosperity of the indigenous people was still questioned. Even in the early of the twentieth century there had been emerging an issue of deminishing indigenous welfare in Java. It finally resulted the Ethical Policy aiming at the welfare of indigenous and then followed by a set of reforms in infrastructures, agriculture, health, industry, etc.

Chapter 6 entitles "The Constraints of a Colonial Economy, 1914 - 1942". This period was characterized by a variety of political and military upheaval spawned World War I and II, which ultimately also affected the performance of the world economy in the form of world economic crisis in 1930s. One interesting thing is that, while economic growth faced serious obstacles, but this period has provided vast opportunities for the emergence of new institutions and organizations in economy, social and politics in Indonesia.

Meanwhile period of twenty-five years after the defeat of the Dutch over Japan to be analyzed in Chapter 7 under the title "The Lost Decade? 1942 to 1967". This period is the most depressing period in the history of Indonesia. In a short period, the people of Indonesia must undergo a very ruthless military occupation during the Pacific War. After that, the Indonesian people also had experienced the Independence war which was then followed by the uncertainty in the direction of the economic development in the 1950s. EHI concludes that the first years of independence ended in a nightmare, i.e. the economic and political instability of the mid-1960s resulted in the military coup of 30 September 1965, Suharto's counter coup, and the massacre of hundreds of thousands of (alleged) communists.

Period between 1967 and 1998 is discussed in Chapter 8 under the title "Success and Failure of the 'New Order', 1967 - 1998'. In this chapter the EHI proposes that during this period Indonesia could reach highly successful economy from being one of the leastdeveloped economy in the world, with a small manufacturing sector, it developed into a major exporter of manufactured goods. On average, GDP per capita increased by 4.6 per cent anually, much faster than its market access, pointing towards structural improvements in its international competitiveness. And Indonesia also was able to start catching up with the productivity leader in the world economy.

In the last chapter (Chapter 9 "Crisis, Recovery and the Evolution of Living Standards since Independence”) the EHI states that 
Indonesia has made slow but significant progress since the Asian Crisis started in 1997. Indonesia moved from authoritarian rule to democracy in less than a decade, and growth has returned, backed by prudent macroeconomic management. With an optimistic tone, the EHI convinces that since the end of the 1960s, "Indonesia has really been experiencing 'modern economic growth' and its recent political development seems to have created a solid basis for its continuation in the future".

\section{Finding the Forces behind the Growth}

One of the most interesting things in this book is its attempt to discover the forces behind the dynamics of the economic history of Indonesia. Over the last two hundred years (1800 -2012), Indonesia has experienced the rhythm of economic development in the form of a very dynamic growth, crisis, stagnation, recovery, and even the condition of almost collapse. Such dynamics are not well understood without analyzing the long-term economic development. One will not be able to find the core strengths that determine economic development in Indonesia in particular and Asia in general without using a long-term historical approach. In the midst of the economic downturn of former colonial countries of South and Southeast Asia in the mid-1960s, for example, Gunnar Myrdal has seen economic conditions of South and Southeast Asia with a very pessimistic. He stated that the failure of economic development in the countries of the former colonies in Asia stems from the traditional power structure that does not allow these countries to apply modern development programs. He proposes that the failure of development planning is the key to understanding the Asian Drama.

Exactly 25 years after the pessimistic publication of Myrdal, conversely the World Bank published a very optimistic study entitles The East Asian Miracle: Economic Growth and Public Policy. This study finds that large parts of Asia had found the ideal formula of "growth with equity". Instead of concentrating on inward-looking industrialization policies, they focused on exports of industrial commodities, and making use of their surpluses of relatively cheap labor. East and Southeast Asian countries had learnt from the mistakes made during the immediate post-war years and they were doing almost everything right.

What is the relevance of the two books to understand the economic development of Indonesia? In this regard, Indonesia is an interesting example of a process of transformation of the 'drama' to 'miracle'. As it is known that in the mid-1960s Indonesia was facing a problem of political instability and economic contraction. And in the first half of the 1990s (when the World Bank study conducted) Indonesia had become 'the brightest boys in the classroom'. It is very interesting that unprecedented path of growth came into an abrupt end during the Asian crisis in 1997/1998. Again, Indonesia surprised economists. The economists then conclude that the growth of Indonesia's economy is characterized as erratic with high degree of discontinuity which became the interesting theme of further studies.

Prof. Van Zanden and Dr. Marks raise a question of why Indonesia which is very rich in natural resources remains poorer than 'average', and much poorer than the productivity leaders in the world economy? Many experts have attempted to answer this question. Anne Booth, for example, focuses on the analysis of the wrong policies that caused the economic problems. It seems that economic historians have tended to blame the policies made by the regime in the past. Meanwhile, Pierre van der Eng argues, before judging that the past economic policy was wrong, historians must understand that the government of the time had different options that might be based on the specific reasons why they chose the 'wrong policy'. Prof. Van Zanden and Dr. Marks argue that economic growth is influenced by many factors, including the wrong policy. They state that in order to understand 
the 'mistakes policy', we must understand the political prosesses they were part of, and the institutions governing the polity involved. This explains that EHI pays much attention to policies by trying to understand them on the basis of an analysis of the 'underlying' layer of institutions that tend to define the range of options policymakers can choose from. Based on the analysis on trend of economic development in Indonesia over the past 200 years, Prof. Van Zanden and Dr. Marks show that the process of Indonesian economic growth have been shaping by the growth of inputs, total factor productivity growth, institutional, and geographical forces. These are the powers behind the Indonesian economic growth. 